\title{
Growth Response of Four Conilon Coffee Varieties (Coffea canephora Pierre ex A. Froehner) to Different Shading Levels
}

\author{
Bruno dos Passos Assis ${ }^{1}$, Eduardo Gross ${ }^{2}$, Norma Eliane Pereira ${ }^{2}$, Marcelo Schramm Mielke ${ }^{3}$ \\ $\&$ Gedeon Almeida Gomes Júnior ${ }^{1}$ \\ ${ }^{1}$ Programa de Pós-Graduação em Produção Vegetal, Universidade Estadual de Santa Cruz, Bahia, Brazil \\ ${ }^{2}$ Departamento de Ciências Agrárias e Ambientais,Universidade Estadual de Santa Cruz, Bahia, Brazil \\ ${ }^{3}$ Departamento de Ciências Biológicas,Universidade Estadual de Santa Cruz, Bahia, Brazil \\ Correspondence: Eduardo Gross, Departamento de Ciências Agrárias e Ambientais, Universidade Estadual de \\ Santa Cruz (UESC), Rod. Jorge Amado, Km 16 Ilhéus, BA, 45662-900, Brazil. Tel: 55-733-680-5191. E-mail: \\ egross@uesc.br
}

Received: February 11, $2019 \quad$ Accepted: March 18, $2019 \quad$ Online Published: May 31, 2019

doi:10.5539/jas.v11n7p29 URL: https://doi.org/10.5539/jas.v11n7p29

The research is financed by CNPq grant 403085/2017-9.

\begin{abstract}
In order to select a conilon coffee (Coffea canephora Pierre ex A. Froehner) adapted to shade, four varieties (C153, JM2, LB1 and GG) were submitted to four shade levels $(0,30,50$ and 70$)$ with evaluation of plant height, stem diameter, collar diameter, number of plagiotropic branches, number of fruits, root colonization by arbuscular mycorrhizal fungi and leaf anatomy. The experiment was carried out on a completely randomized design, in a $4 \times 4$ factorial scheme with ten replicates. We used organic compost based on cocoa shells for plant nutrition and cow urine for phytopathogenic fungi control. There was interaction between variety and shade factors for most of coffee characteristics analyzed. In general all coffee characteristics evaluated mainly fruit number and length of fruiting branches, significantly increased with increasing shade. Coffee varieties tested respond differently to the increasing of shade levels and leaf anatomy demonstrated the reduction of mesophyll thickness as the shading increased. The effect of shade levels on fruit yield fit to a positive linear regression for all four coffee varieties tested but the mycorrhizal colonization no presented differences among coffee varieties and shade levels. The varieties C153 and GG presented highlighted anatomical, growth and productive characteristics and can be indicated for shading cultivation, for example on agroforestry systems.
\end{abstract}

Keywords: shade, organic fertilizer, leaf anatomy

\section{Introduction}

Brazil is the world's largest producer and exporter of coffee and the State of Bahia is the third largest producer of conilon coffee (Coffea canephora Pierre ex A. Froehner) on Brazil. According to data released in the annual survey of the coffee harvest conducted by CONAB, the main coffee conilon producing states in 2018 are: Espírito Santo, Rondônia and Bahia, which is responsible for approximately $13.66 \%$ of the national production of this coffee species (CONAB, 2018).

Known worldwide as robusta coffee or conilon coffee, mainly due to its rusticity and resistance to diseases, it is the second most cultivated species in the world, with about $40 \%$ of coffee production (ICO, 2017). It has a wide geographical distribution, is a rustic species, resistant to pests and diseases, more tolerant to water stress and high temperatures, and because it originates in tropical forests, more adapted to hot and humid climate regions, presenting even greater productivity when compared to Arabic coffee (CONAB, 2018). In Bahia, the conilon coffee was introduced by the state of Espírito Santo, and nowadays the crop production is a result of the expansion of the cultivated area in the last fifteen years (CEPLAC, 2017).

Several environmental factors, especially the incidence of radiation, can cause changes in plant development and shading provides the development of higher plants, larger and thinner leaves, with larger crown diameter, allowing a better capture of the available solar energy, specially for shade-tolerant trees (Givnish, 1988), as 
conilon coffee. Shading can modify structural and functional characteristics of the leaves, influencing changes in the pattern of plant growth and production (Bjorkman, 1981). The plants submitted to a low luminosity condition develop anatomical changes, which play an important role in adapting the plant to the conditions imposed by the environment. These changes are related to increased uptake and utilization of incident light, a feature that limits shade growth, increasing the photosynthetic efficiency of the plant (Lambers et al., 1998). According to Castro et al. (2009) the leaf is one of the most plastic organs in response to environmental factors, and the variations resulting from these factors are observed in the foliar tissues in the attempt to adapt the plant. The knowledge of the leaf anatomy of the coffee tree is important to understand several physiological processes of the plant (Camargo \& Marenco, 2011).

The study of the plant-microorganisms relationship have been intensified in the last decades, mainly due to the great importance that the microorganisms exert in the maintenance of the life, balance and restoration of ecosystems. The coffee tree has high mycorrhizal dependence, being this association favored mainly in low fertility soils (Lopes et al., 1983; Siqueira \& Colozzi-Filho, 1986). The benefits that arbuscular mycorrhizal fungi (AMF) bring with the absorption of other nutrients have been well studied and they are efficient and of great importance for the plant nutrition (Moreira et al., 2010).

The evaluation of the type and magnitude of physiological, anatomical and morphological alterations that occur in plants submitted to reducing irradiation can contribute to the selection of more adapted and shade tolerating plant varieties. The objective of this research was to verify the effect of different shading levels on four different conilon coffee varieties evaluating the growth, yield and leaf anatomy, as well as AMF root colonization, in order to provide subsidies to technicians and coffee producers on the appropriate choice of variety suitable for cultivation on agroforestry systems.

\section{Materials and Methods}

The experiment was carried out in an experimental area located at the Universidade Estadual de Santa Cruz (UESC) located in the municipality of Ilhéus (Bahia State), from July 2016 to December 2017. The experiment site is located at $39^{\circ} 10^{\prime} 20.586^{\prime \prime} \mathrm{W}, 14^{\circ} 47^{\prime} 47.769^{\prime \prime} \mathrm{S}$ at $44 \mathrm{~m}$ above sea level. According to Köppen the climate classification is Af. with $24.4{ }^{\circ} \mathrm{C}$ of average temperature. The average annual rainfall is $1,419 \mathrm{~mm}$ (CLIMATE-DATA.ORG, 2017).

The soil used on experiment was obtained from surface horizon of a typical dystrophic yellow Latosol and was air-dried and sieved in a $5 \mathrm{~mm}$ thick mesh. The soil presented the following chemical characteristics: $\mathrm{pH}$ in $\mathrm{H}_{2} \mathrm{O}$ $=5.08$; organic matter $(\mathrm{OM})=4.18 \mathrm{dag} \mathrm{kg}^{-1} ; \mathrm{P}($ Mehlich 1$)=11.4 \mathrm{mg} \mathrm{dm}^{-3} ; \mathrm{K}=64 \mathrm{mg} \mathrm{dm}^{-3} ; \mathrm{Ca}=4.49 \mathrm{cmolc}^{-3}$ $\mathrm{dm}^{-3} \mathrm{Mg}=3.28 \mathrm{cmolc} \mathrm{dm}^{-3} ; \mathrm{Al}=0.0 \mathrm{cmolc} \mathrm{dm}^{-3}$; sum of exchangeable bases $=7.93 \mathrm{cmolc} \mathrm{dm}^{-3}$; cation exchange capacity $=12.33 \mathrm{cmolc} \mathrm{dm}^{-3} ; \mathrm{Cu}, \mathrm{Fe}, \mathrm{Zn}$ and $\mathrm{Mn}\left(\mathrm{mg} \mathrm{dm}^{-3}\right)=2.32 ; 31.3 ; 12.21 ; 160.8$; percent base saturation $=64.3$. After the analysis, the $\mathrm{pH}$ was corrected to 6.0 using the incubation curve method (Gomes et al., 2008).

The organic compost used on experiment was produced in the UESC field area, using cocoa shells added to pruning residues of grasses. At 180 days after composting the material was dried at room temperature and then sieved. Its chemical composition showed the following results: $\mathrm{pH}$ in $\mathrm{CaCl}_{2}=6.05 ; \mathrm{P}=128.3 ; \mathrm{K}=557 ; \mathrm{Cu}=$ 1.53; $\mathrm{Mn}=86.6 ; \mathrm{Zn}=16.3 ; \mathrm{Fe}=48.9\left(\right.$ all in $\left.\mathrm{mg} \mathrm{kg}^{-1}\right) ; \mathrm{Ca}=12.12 ; \mathrm{Mg}=5.07 ; \mathrm{Al}=0.0 ; \mathrm{H}+\mathrm{Al}=1.9$ (all in $\left.\mathrm{cmolc} \mathrm{dm}^{-3}\right) ; \mathrm{OM}=48.36 \mathrm{dag} \mathrm{kg}^{-1}$; remaining $\mathrm{P}=57.9 \mathrm{mg} \mathrm{L}^{-1}$.

The experiment was a completely randomized design, on a $4 \times 4$ factorial scheme, the factors being four levels of shading $(0 \%, 30 \%, 50 \%$ and $70 \%)$ and four varieties of conilon coffee (C153, JM2, LB1 and GG), with 10 replications per treatment. Coffee seedlings were transplanted into $20 \mathrm{~L}$ plastic pots filled with a 9:1 (v/v) mixture of soil and organic compost. The amount of compost mixed to the soil was established according to the $\mathrm{K}$ nutritional requirement of the crop for the first year of cultivation $\left(60 \mathrm{mg} \mathrm{dm}^{-3}\right)$, which corresponded to $2 \mathrm{~kg}$ of the organic compost. The same amount of compost was added to the soil 180 days after transplanting.

At 18 months after transplanting, when the coffee trees were on fruiting season, the following variables were evaluated: plant height, collar diameter, length of main branch, number of plagiotropic branches, number of fruits per plant, arbuscular mycorrhizal fungi (AMF) colonization of roots and number of AMF spores in soil.

For the anatomical evaluations of the coffee varieties, three completely expanded leaves of the third node of plagiotropic branches were collected and were cut in the middle third with razor blades and prepared according to Johansen (1940). The anatomical sections were made according to O'Brien et al. (1964). To determine the stomatal density, the technique of scanning electron microscopy was used. Measurements of the thickness of the 
leaf blade, mesophyll, palisade and spongy parenchyma were made in three regions distinct from each section on a total of 15 measurements for each treatment.

Photosynthetically active radiation (PAR) was obtained using the quantum line sensor (LI 191 SA, LICOR Inc., Lincoln, Nebraska, USA). Data were recorded and stored in a datalogger (LI 1400, LICOR Inc., Lincoln, Nebraska, USA). Measurements were made between 06:00 and 18:00 h during the 18 months of cultivation. The monthly values of global solar radiation were obtained by summing the daily values and expressed in mole of photons per day

Mycorrhizal colonization was evaluated according to the methodology described by Phillips and Hayman (1970). To estimate the number of AMF spores present in the soil, the wet sieving methodology (Gerdemann \& Nicolson, 1963) was used using a stereomicroscope.

Plant growth, coffee production and the leaf anatomical data were submitted to the Shapiro-Wilk and Levene tests in order to verify residual normality and homoscedasticity. Then ANOVA was performed to test for the effect of varieties and shade levels and for significance of interaction using $\mathrm{R}$ statistical program. Plant growth and coffee production data were evaluated by using polynomial linear and non-linear regression analyses, and significant different leaf anatomical data were submitted to the Tukey's post hoc test at $5 \%$.

\section{Results and Discussion}

In our study PAR characterization demonstrated the highest levels of solar incidence during spring and summer (Figure 1) in accordance with were observed by Pereira et al. (2017) for the Northeast Brazilian region. Solar radiation is practically the only source of energy for the physiological and biochemical processes that occur in plants. Biomass production of a plant depends, in one instance, on the leaves efficiency to convert radiant energy into chemical energy through photosynthesis (Assis \& Mendez, 1989). PAR analysis is important for studies on plant growth rate, biomass production, photosynthetic rate and stomatal conductance, since it is the radiation that excites plant chlorophyll molecules, initiating energy flow during the photosynthesis process (Frasina et al., 2003)

Although growth variations were observed among the varieties for the same level of luminosity, our results indicate that value of $50 \%$ of shade is ideal for coffee cultivation. This is in part explained since conilon coffee is a tropical species that has evolved in shaded environments of African forests (Kumar \& Tieszen, 1980; Fahl et al., 1994), and can be cultivated at low light radiation environments (ranging from 300 to $600 \mathrm{mmol} \mathrm{m} \mathrm{m}^{-2}$ of saturation irradiance).

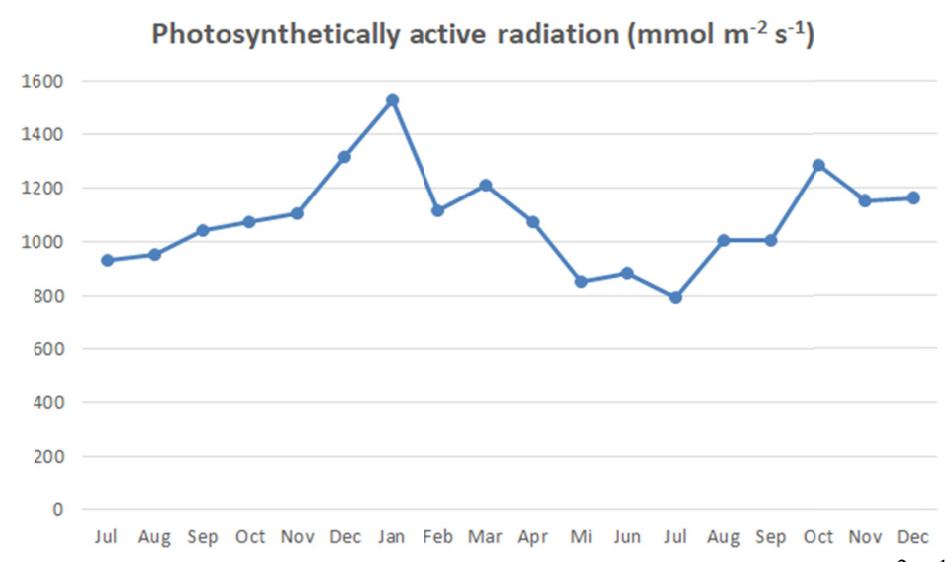

Figure 1. Monthly averages of photosynthetically active radiation (PAR) $\left(\mathrm{mmol} \mathrm{m}^{-2} \mathrm{~s}^{-1}\right)$ on eighteen month experiment of conillon coffee cultivation at Ilheus, Bahia State, Brazil

According to the regression analysis plant height showed significant effect of variety and shade level interaction for C153 and LB1, which responded to shade levels presented curvilinear increments with the quadratic adjustments (Figure 2). Dardengo et al. (2013) reported in their study that shaded conilon coffee plants showed higher growth than full sun (no shading) plants. Our results also resembled Morais et al. (2003) that verified the growth of the coffee shade with pigeon pea and in full sun, demonstrated that low level of radiation incident on the shaded pigeon peas resulted in a higher plant height. Braun et al. (2007) analyzing the production and growth 
of conilon coffee seedlings at different shade levels found a better development for plant height when increasing the shadow.

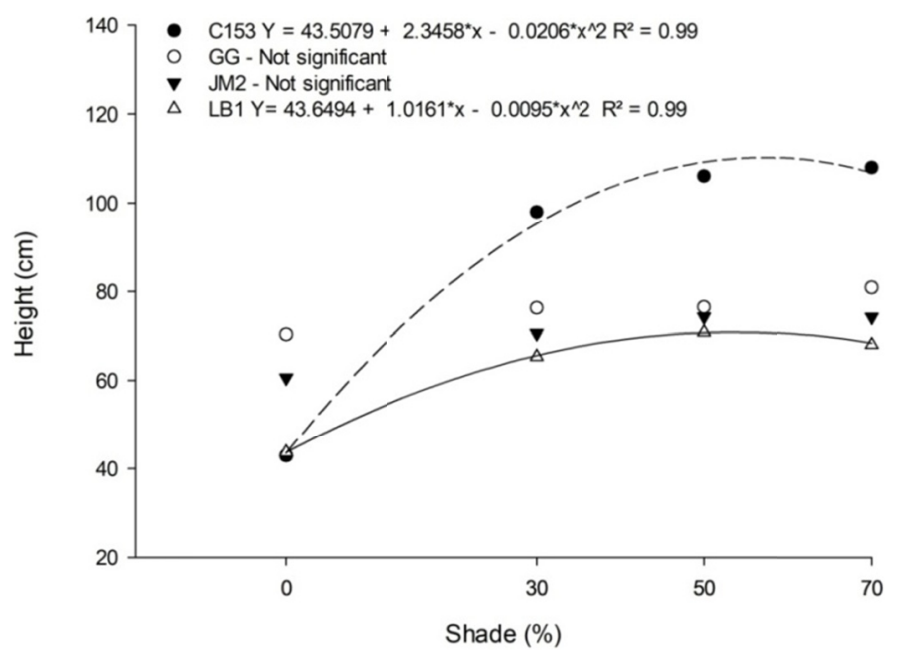

Figure 2. Height of conilon coffee varieties evaluated under different shade levels

For the crown diameter regression analysis showed that shade levels significantly influenced the development of the varieties. Crown diameter increases until $50 \%$ of shade level, decreasing at $70 \%$ of shading in a quadratic response (Figure 3). C153 variety showed lowest development when submitted to cultivation at full sun but it was superior to the others when the level of shade was increased (Figure 3).

Our results disagree with observed by Lemos and Matsumoto (2009) that evaluated the planting of conilon coffee shaded by forest species and cultivation at full sun, finding no significant difference for crown diameter on these different environments. Araújo et al. (2014) studying development of banana shaded coffee observed no significant morphological differences in coffee trees.

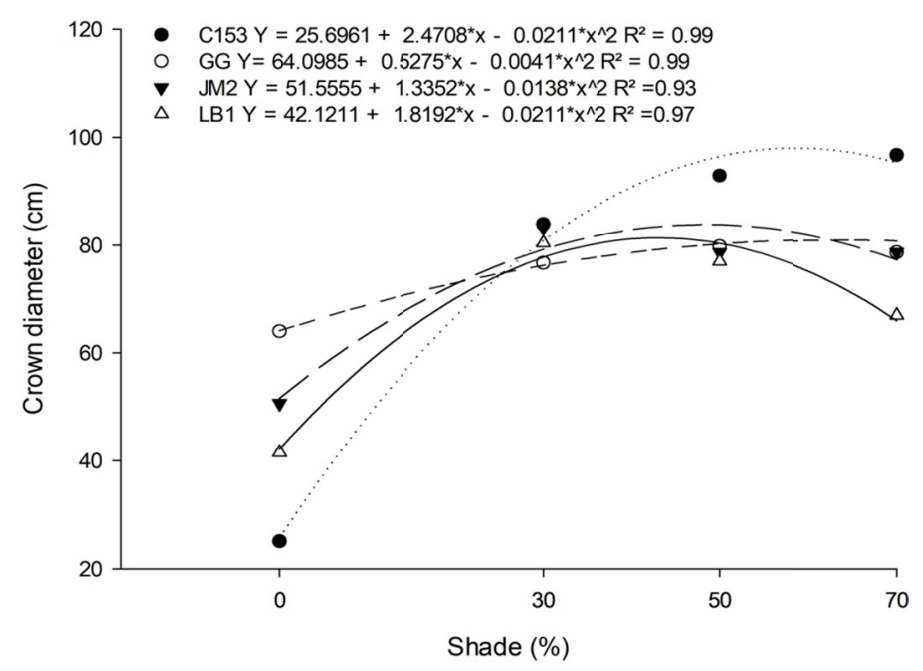

Figure 3. Crown diameter of conilon coffee varieties evaluated under different levels of shade

Main branches of four conilon coffee varieties evaluated presented lower growth when submitted to full sun cultivation (Figure 4). According to Berthaud and Charrier (1988) the natural habitats of C. canephora are the understorey of the African rainforests, and this environment is more conducive to its development. 


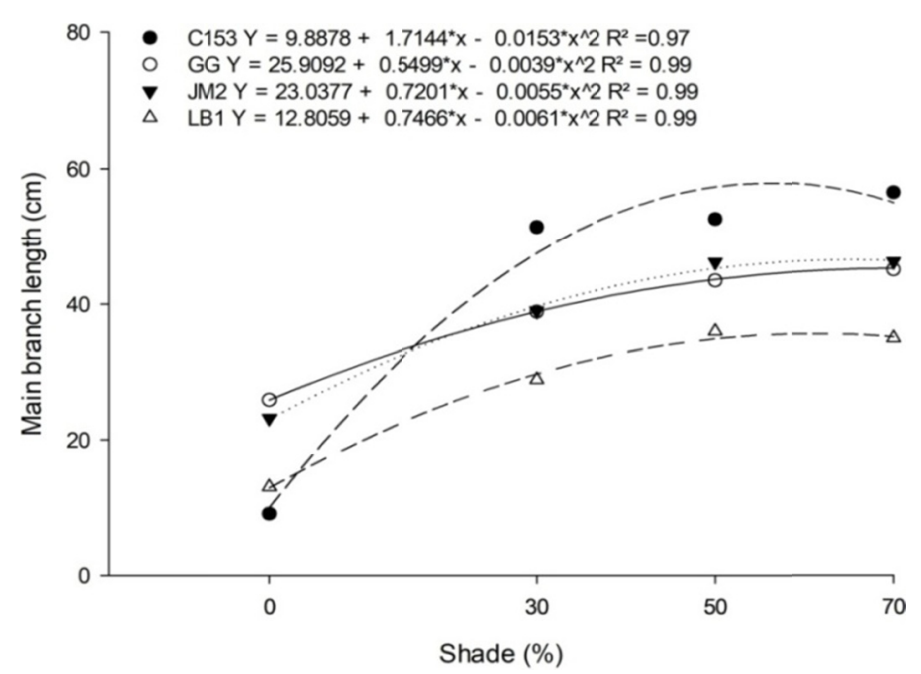

Figure 4. Length of plagiotropic branch of conilon coffee varieties evaluated under different levels of shade

Regarding the number of branches, according to the regression analysis JM2 did not respond significantly to the levels of shading. For the other three varieties the response was quadratic and the shading provided an increase in the number of productive branches when compared to the plants at full sun (Figure 5). A similar result was observed by Ricci et al. (2013), which reported higher number of plagiotropic branches for coffee shaded by Gliricidia sepium the coffee cultivated at full sun. Araújo et al. (2016) reported that shading induces coffee to increase the length of plagiotropic branches, an effect that is possibly associated with etiolated plants. According to Fernandes (1986), the shading can bring satisfactory results when compared to the cultivation in full sun, some benefits are the improvement of the vegetative aspect of the coffee tree, increasing the number of primary and secondary branches and consequently increasing in coffee production.

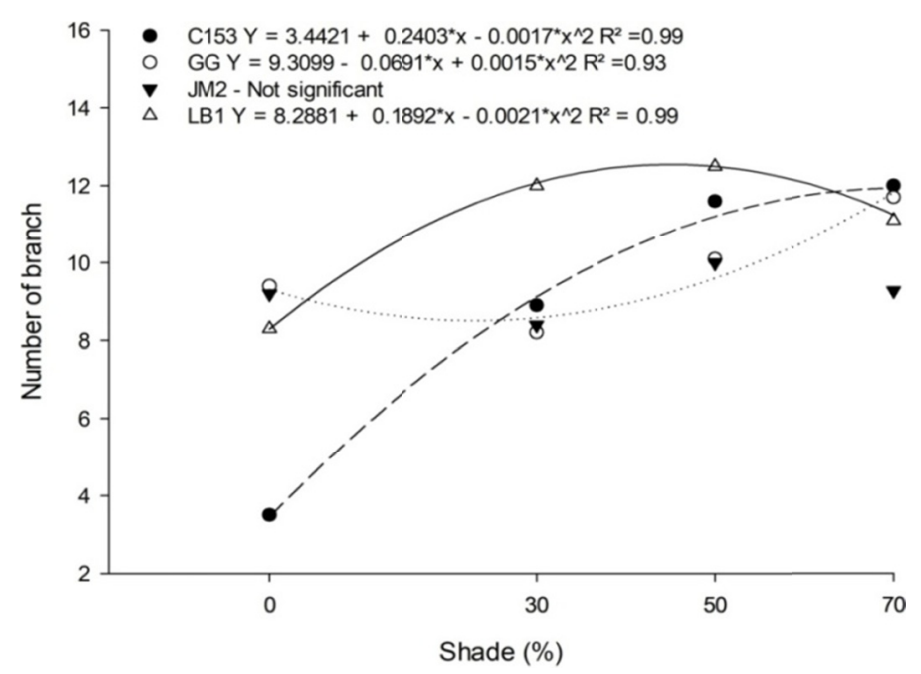

Figure 5. Number of branches in conilon coffee varieties evaluated under different levels of shade

The plant collar diameter was significantly influenced by the interaction of variety and shade factors $(p \leq 0.05)$. According to the regression analysis the collar diameter of GG variety did not respond significantly to shade levels. The clones JM2 presented linear response and for clones C153 and LB the adjustment was quadratic (Figure 6). Braun et al. (2007) analyzing diverse growth parameters of conilon coffee seedlings observed that only the collar diameter was not influenced by different shade levels. 


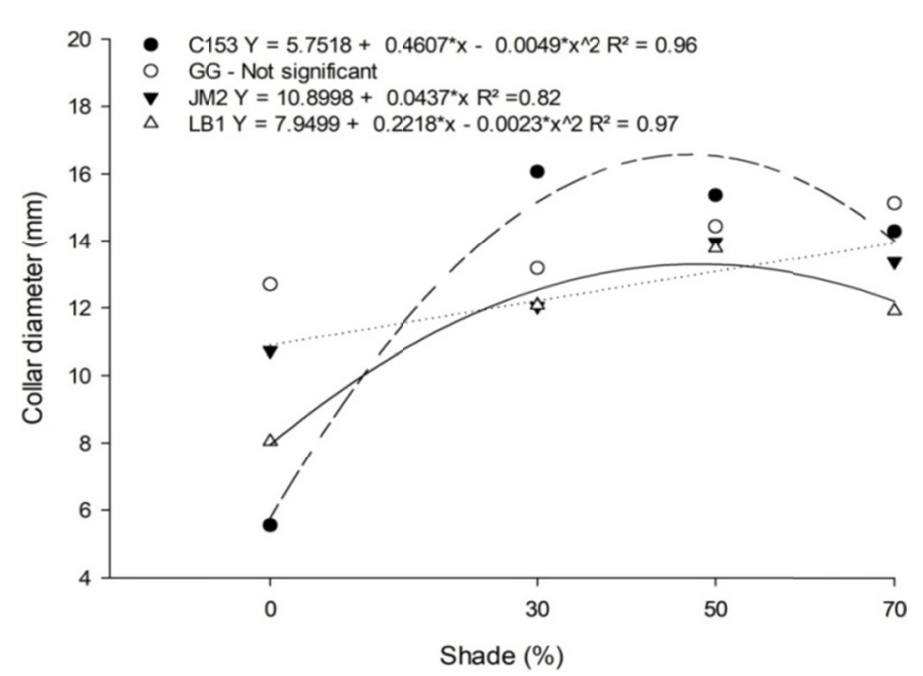

Figure 6. Collar diameter of conilon coffee varieties evaluated under different levels of shade

Dardengo et al. (2013) reported that growth and quality of conilon coffee seedlings were influenced by shading and pot diameter but the collar diameter was not influenced by pot types and shade levels.

Plant height and collar diameter are two parameters widely used to determine the growth rate of plants in response to shade levels, since the capacity to grow in shade conditions is a mechanism of plant adaptation (Moraes Neto et al., 2000). The growth in stem diameter is stimulated by carbohydrates produced by photosynthesis and phytohormones synthesis, since growth in diameter is a good indicator of the net assimilation (Engel, 1989).

The number of fruits per plant was also significantly influenced by the interaction between coffee variety and shade levels $(\mathrm{p} \leq 0.05)$. The number of fruits per plant increased in response to shade levels in all coffee varieties tested, with a linear regression adjustment (Figure 7). This result suggests the possibility of better yield results at higher levels of shading.

The flowering is one of the most important physiological processes of the coffee tree (Barros et al., 1978) and depends strictly on the growth of the plagiotropic branches, because in conilon coffee the inflorescences (glomeruli) are formed from serial buds, located randomly at opposite leaves position on lateral branches, which were formed in the growing season of the current year (Moens, 1968; Barros et al., 1978). The process of flowering and consequent fruit formation depends strictly on the radiation (photoassimilates), temperature (physiology) and water availability (metabolism) (Moens, 1968; Barros et al., 1978; Rena et al., 1986; Damatta et al., 2007) that can affect the shaded coffee trees.

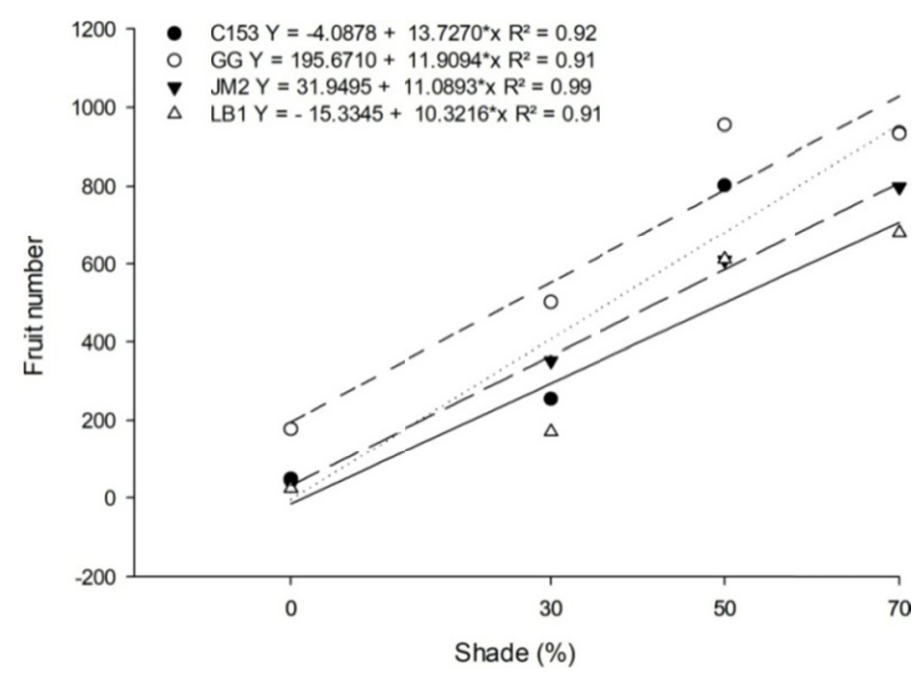

Figure 7. Number of fruits in conilon coffee varieties evaluated under different levels of shade 
The use of perennial species that can be intercropped with coffee, providing shading and consequently increasing the production per cultivated area, also aims at minimizing the adverse effects of climate (particularly dry, high temperature and wind) on the crop production (Damatta et al., 2007). Our study demonstrated that, when shaded, the coffee tree obtained higher production, which is an alternative in reducing production costs, resulting in a diversification when on an agroforestry system. Fruit number results agree with Fernandes (1986), Matiello (1995) and DaMatta et al. (2007) observations that shading increases the productive capacity of the coffee tree.

All plants were mycorrhizal (Figure 8) and AMF spores were found in all soils collected. However, according to the analysis of variance, there was no significant difference when we analyzed the different rates of root colonization and spores in the soil. Regression analysis was not significant for all varieties on four shaded levels tested. This result was probably influenced by organic compost applied in soil that was the same dose for all plants. Also this result can indicate that full sun ( $0 \%$ of shade) may have caused stress increasing mycorrhizal colonization of roots.
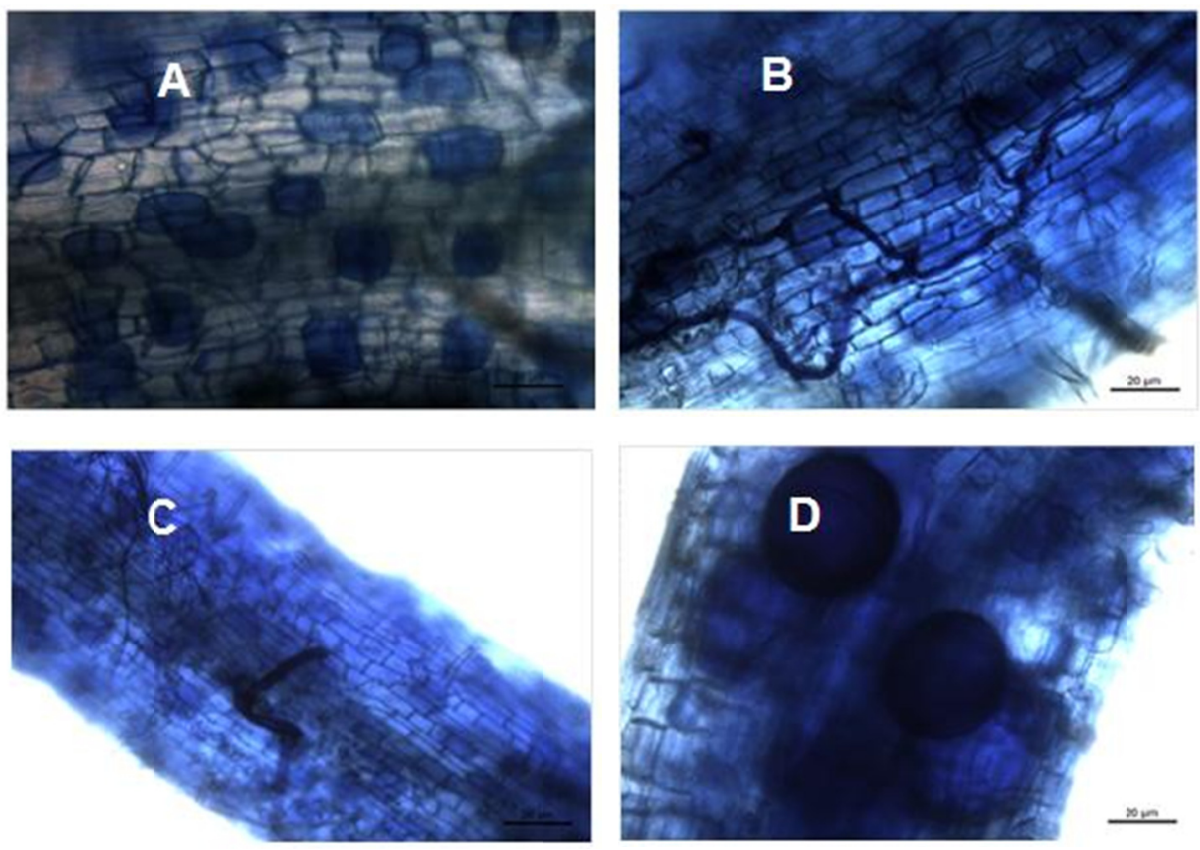

Figure 8. Coffee roots colonized by AMF. (A) General view of a mycorrhized root, where conspicuous arbuscules can be observed (arrows); (B) Overview of a mycorrhized root, where we can observe the hyphae; (C)

Mycorrhizal root, where it can be observed arbúsculos, hyphae and trichomes of the roots; (D) AMF spores

This result is in agreement with other researchers that reported high mycorrhizal dependence for coffee trees (Siqueira \& Collozi-Filho, 1986; Colozzi-Filho et al., 1994), and that stress conditions, such as reduced water availability induce the production of AMF spores for fungus survival and dispersion (Siqueira et al., 1998). The sporulation of AMF in the soil is also quite varied and depends on fungus, plant, soil factors, seasonality or crop management practices (Cardoso et al., 2003). The availability of phosphorus, variations in temperature and rainfall, as well as natural enemies, also have a direct influence on sporulation (Ross \& Daniel, 1982; Balota \& Lopes, 1996; Siqueira et al., 1998).

To know the influence of different shading levels on coffee tree is necessary to determine the optimal levels of solar radiation that provide better development and production of this plant. The availability of light can cause changes in the structural and functional characteristics of the leaves, directly influencing the growth and production (Gomes et al., 2008; Oguchi et al., 2005). The increase in light intensity provides an increase in leaf thickness and stomatal density (Pandey \& Kushwaha, 2005; Stein, 2017).

Our data demonstrated that independently of coffee variety, stomatal density reduced with increasing of shade levels (Figures 9A and 9B). For conilon coffee variety C153 for example, we observed the presence of 122, 111, 91 and 61 stomata at $0,30,50$ and 70\% of shading, respectively. This can be explained by leaf expansion of coffee tree on shading condition. Our results agree with Paiva (2001) that observed in coffee seedlings an 
increasing on stomata number on full sun cultivated plants when compared to shaded coffee plants. The stomata present great importance in anatomical studies, since the increase of the stomatal frequency in leaves exposed to high radiation can be an important mechanism of adaptation of the species to dry conditions (Castro, 2009).

When comparing the leaf blade thickness of the different coffee varieties submitted to the different levels of shade we observed a reduction as shading increase (Figures 9C and 9D). This reduction was observed on mesophyll, palisade and spongy parenchyma thickness (Table 1) that composed the leaf blade.
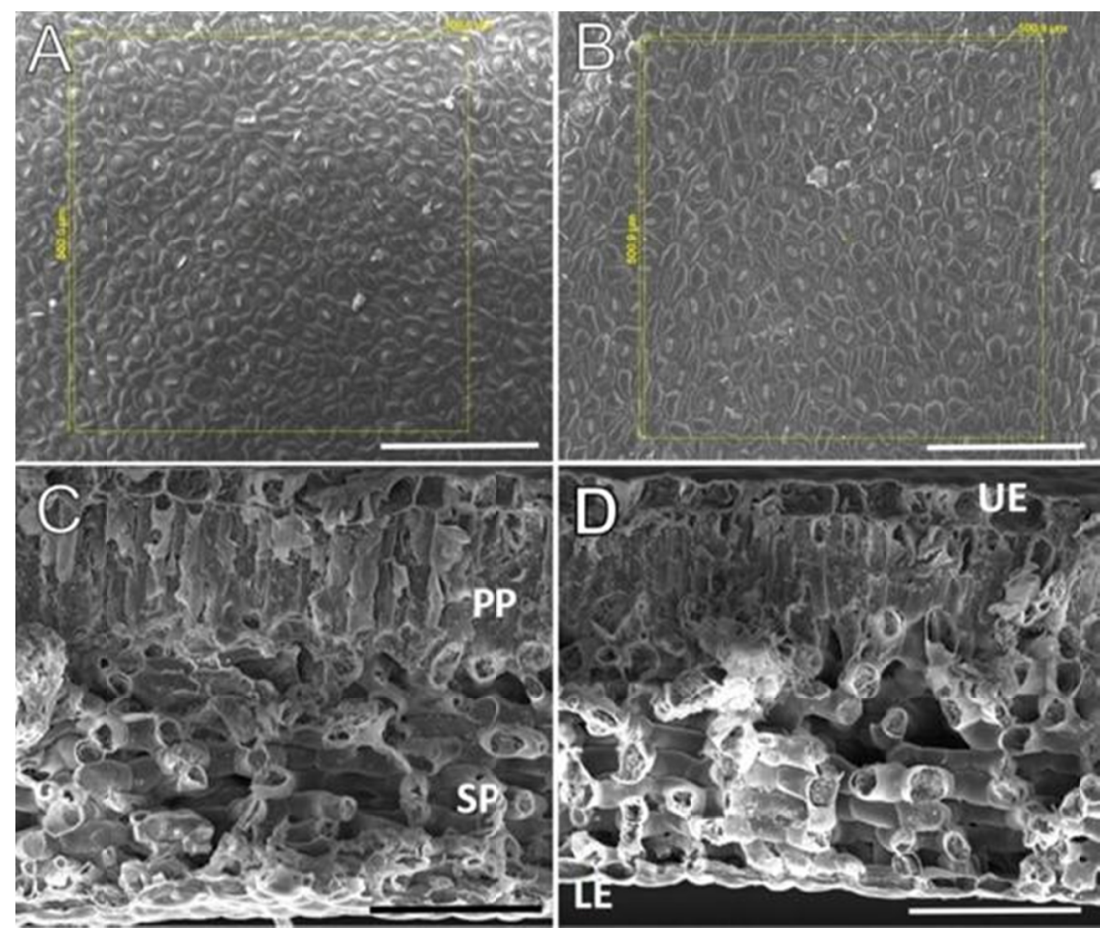

Figure 9. Scanning electron micrograph of conilon coffee leaves. (A), (B) Stomatal density of C153 conilon coffee variety submitted to 0 and $70 \%$ of shade level, respectively. (C), (D) Leaf anatomy of GG conilon coffee variety submitted to 0 and $70 \%$ of shade level, respectively, showing the palisade parenchyma (PP), spongy parenchyma (SP) an the upper (UE) and lower (LE) epidermis. Scale bars: A, B = $200 \mu \mathrm{m} ; \mathrm{C}, \mathrm{D}=100 \mu \mathrm{m}$

The increase in thickness of palisade and spongy parenchyma cells and consequently on leaf blade and mesophyll thickness when the shade level decreased were observed for all four varieties of conilon coffee tested (Table 1). 
Table 1. Leaf, mesophyll and parenchyma thickness $(\mu \mathrm{m})$ of four conilon coffee varieties submitted to four different shade levels

\begin{tabular}{|c|c|c|c|c|}
\hline \multirow{2}{*}{ Variety } & \multicolumn{4}{|c|}{ Shade (\%) } \\
\hline & $\mathbf{0}$ & 30 & 50 & 70 \\
\hline \multicolumn{5}{|c|}{ Leaf blade } \\
\hline GG & $293.3 \mathrm{aC}$ & $290.8 \mathrm{aC}$ & $279.1 \mathrm{bB}$ & $247.8 \mathrm{cC}$ \\
\hline $\mathrm{C} 153$ & $381.1 \mathrm{aA}$ & $330.4 \mathrm{bA}$ & $319.5 \mathrm{cA}$ & $290.6 \mathrm{dA}$ \\
\hline LB1 & $306.4 \mathrm{aC}$ & $287.8 \mathrm{bC}$ & $275.5 \mathrm{cB}$ & $268.9 \mathrm{cB}$ \\
\hline JM2 & $338.5 \mathrm{aB}$ & $300.5 \mathrm{bB}$ & $252.4 \mathrm{cC}$ & $250.4 \mathrm{cC}$ \\
\hline \multicolumn{5}{|c|}{ Mesophyll } \\
\hline GG & $264.6 \mathrm{aD}$ & $259.1 \mathrm{aB}$ & $235.8 \mathrm{bB}$ & $210.6 \mathrm{cC}$ \\
\hline $\mathrm{C} 153$ & $373.3 \mathrm{aA}$ & $273.9 \mathrm{bA}$ & $268.8 \mathrm{bA}$ & $259.3 \mathrm{cA}$ \\
\hline LB1 & $276.5 \mathrm{aC}$ & $253.3 \mathrm{bB}$ & $238.0 \mathrm{cB}$ & $236.4 \mathrm{cB}$ \\
\hline JM2 & $300.1 \mathrm{aB}$ & $269.7 \mathrm{bA}$ & $222.1 \mathrm{cC}$ & $207.9 \mathrm{dC}$ \\
\hline \multicolumn{5}{|c|}{ Palisade parenchyma } \\
\hline GG & $84.3 \mathrm{aB}$ & $59.7 \mathrm{bC}$ & $55.5 \mathrm{bC}$ & $52.1 \mathrm{bC}$ \\
\hline $\mathrm{C} 153$ & $98.0 \mathrm{aA}$ & $90.6 \mathrm{aA}$ & $74.5 \mathrm{bA}$ & $69.9 \mathrm{bA}$ \\
\hline LB1 & $85.9 \mathrm{aB}$ & $71.7 \mathrm{bB}$ & $62.0 \mathrm{cB}$ & $60.3 \mathrm{cB}$ \\
\hline JM2 & $86.4 \mathrm{aB}$ & $83.1 \mathrm{aA}$ & $74.4 \mathrm{bA}$ & $64.0 \mathrm{cAB}$ \\
\hline \multicolumn{5}{|c|}{ Spongy parenchyma } \\
\hline GG & $202.9 \mathrm{aC}$ & $180.1 \mathrm{bC}$ & $177.3 \mathrm{bB}$ & $150.1 \mathrm{cB}$ \\
\hline $\mathrm{C} 153$ & $245.6 \mathrm{aA}$ & $208.3 \mathrm{bA}$ & $194.4 \mathrm{cA}$ & $164.5 \mathrm{dA}$ \\
\hline LB1 & $194.1 \mathrm{aC}$ & $181.9 \mathrm{bC}$ & $175.8 \mathrm{bcBC}$ & $167.7 \mathrm{cA}$ \\
\hline JM2 & $223.0 \mathrm{aB}$ & $195.6 \mathrm{bB}$ & $165.5 \mathrm{cC}$ & $136.2 \mathrm{cC}$ \\
\hline
\end{tabular}

Note. Means values with the same lowercase letters in a row and with the same capital letters in a column are not significantly different by Tukey test $(\mathrm{P}>0.05)$.

The difference among leaf thickness of non shaded and shaded conilon coffee plants can be observed on Figure 10. Also we noted that, regardless of variety, the studied conilon coffee presented dorsiventral mesophyll (Figure 10). The palisade parenchyma is dense and composed by elongated cells perpendicular arranged to adaxial surface of the leaf (Figures 9C, 9D and 10). The spongy parenchyma presented large intercellular spaces (Figures 9C, 9D and 10).

The decrease on leaf blade thickness of the shaded conilon coffee probably occurred due to the leaf blade expansion and difference on photoassimilates distribution in relation to full sun cultivated plants, which presented thicker leaves. Our results corroborate those of Voltan et al. (1992) and Cordeiro-Gomes (2008) who verified that leaves of coffee trees exposed to higher levels of radiation had a greater thickness of the leaf blade. This increase in mesophyll thickness causes reduction of the specific leaf area, which, according to some authors, propitiates to full sun plants a greater photosynthetic capacity per unit of leaf area when compared to shaded plants (Niinemets et al., 1998). 

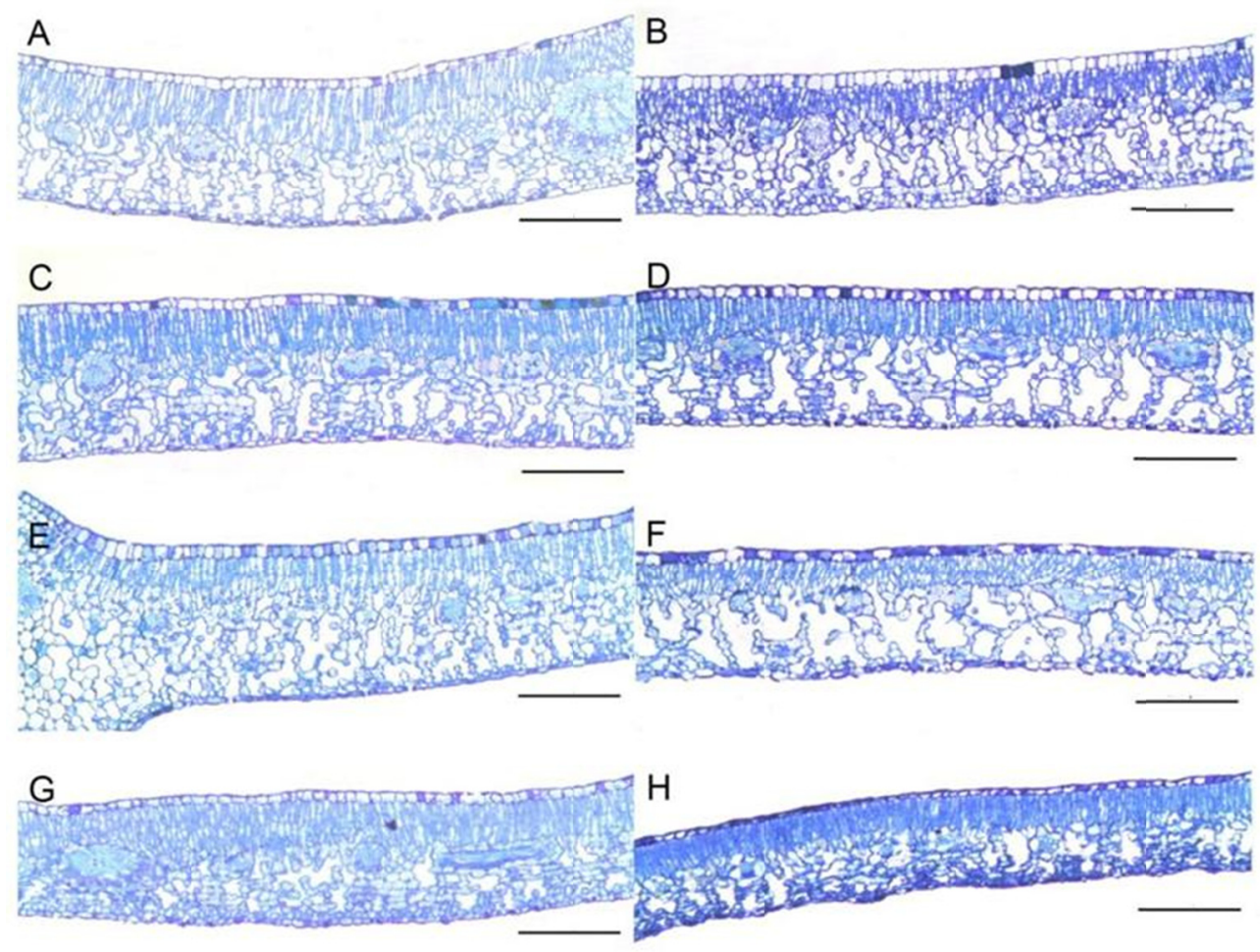

Figure 10. Light micrographs of conilon coffee leaves. A, B. Comparative images of C153 conilon coffee variety submitted to 0 and $70 \%$ of shade level, respectively. C, D. Comparative leaf thickness of LB1 conilon coffee variety submitted to 0 and $70 \%$ of shade level, respectively. E, F. Comparative leaf thickness of GG variety submitted to 0 and $70 \%$ of shade level, respectively. G, H. Comparative leaf thickness of JM2 variety submitted to 0 and $70 \%$ of shade level, respectively. All scale bars $=100 \mu \mathrm{m}$

Leaf blade thickness and stomatal density may vary according to plant location and degree of sun exposure and changes in leaf anatomy is a common attribute of species that present a wide potential for acclimation in response to different levels of light and seems to occur with conilon coffee. This ability is an adaptive response related to genetic characteristic and is influenced by environmental conditions and management.

\section{Conclusions}

The four conilon coffee varieties tested presented an increasing of fruit production when the shade level increase demonstrating that microclimate with reduced dryness, temperature and wind can result on high coffee yield. In the same direction, the varieties C153 and GG of conilon coffee, which presented highlighted anatomical, growth and productive characteristics, can be indicated for shading cultivation manly on agroforestry systems.

\section{References}

Araújo, A. V., Partelli, F. L., Oliosi, G., \& Macedo Pezzopane, J. R. (2016). Microclimate, development and productivity of robusta coffee shaded by rubber trees and at full sun. Revista Ciencia Agronomica, 47(4), 700-709. https://doi.org/10.5935/1806-6690.20160084

Araújo, A. V., Partelli, F. L., Oliveira, M. G., Pezzopane, J. R. M., Falqueto, A. R., \& Cavatte, P. C. (2014). Microclima e crescimento vegetativo do café conilon consorciado com bananeiras. Coffee Science, 10(2), 214-222.

Assis, F. de, \& Mendez, M. (1989). Relação entre radiação fotossinteticamente ativa e radiação global. Pesquisa Agropecuária Brasileira, 24(7), 797-800.

Balota, E. L., \& Lopes, E. S. (1996). Introdução de fungo micorrízico arbuscular no cafeeiro em condições de campo: I. Persistencia e interação com espécies nativas. Revista Brasileira de Ciência do Solo, 20(1), 217-223.

Barros, R. S., Maestri, M., \& Coons, M. P. (1978). The physiology of flowering in coffee: a review. Journal of Coffee Research, 8(2-3), 29-73. 
Berthaud, J., \& Charrier, A. (1988). Genetic resources of Coffea (pp. 1-42).

Bjorkman, O. (1981). Responses to different quantum flux densities. In O. L. Lange, P. S. Nobel, C. B. Osmond, \& H. Ziegler (Eds.), Encyclopedia of plant physiology (pp. 57-107). Berlin, Germany: Springer-Verlag. https://doi.org/10.1007/978-3-642-68090-8_4

Braun, H., Zonta, J. H., Soares De Souza Lima, J., \& Fialho Dos Reis, E. (2007). Produção de mudas de café 'conilon' propagadas vegetativamente em diferentes níveis de sombreamento. Idesia, 25(3), 85-91. https://doi.org/10.4067/ S0718-34292007000300009

Camargo, M., \& Marenco, R. (2011). Density, size and distribution of stomata in 35 rainforest tree species in Central Amazonia. Acta Amazonica, 41(2), 205-212. https://doi.org/10.1590/S0044-59672011000200004

Cardoso, I. M., Boddington, C., Janssen, B. H., Oenema, O., \& Kuyper, T. W. (2003). Distribution of mycorrhizal fungal spores in soils under agroforestry and monocultural coffee systems in Brazil. Agroforestry Systems, 58(1), 33-43. https://doi.org/A:1025479017393

Castro, E. M., Pereira, F. J., \& Paiva, R. (2009). Histologia vegetal: Estrutura e função de órgãos vegetativos. Lavras, Brazil: Editora UFLA.

CEPLAC. (2017). Radar do Café. Retrieved from http://www.ceplac.gov.br/radar/cafe.htm

CLIMATE-DATA.ORG. (2017). Dados climáticos para cidades mundiais. Retrieved from https://pt.climate-data.org

Colozzi-Filho, A., Siqueira, J. O., Junior, O. J. S., Guimarães, P. T. G., \& Oliveira, E. (1994). Efetividade de diferentes fungos micorrízicos arbusculares na formação de mudas, crescimento pós-transplante e produção do cafeeiro. Pesquisa Agropecuária Brasileira, 29(9), 1397-1406.

CONAB (2018). Café conilon-Brasil, Safras 2008 a 2018. Retrieved from http://www.conab.gov.br/conteudos. php?a=1252

Cordeiro Gomes, I. A., de Castro, E. M., Soares, A. M., Donizeti Alves, J., Nogueira Alvarenga, M. I., Alves, E., ... Deitos Fries, D. (2008). Alterações morfofisiológicas em folhas de Coffea arabica L. cv. "Oeiras" sob influência do sombreamento por Acacia mangiumWilld. Ciência Rural, 38(1), 109-115. https://doi.org/10.1590/S0103-84782008000100018

Damatta, F. M., Ronchi, C. P., Sales, E. F., \& Araújo, J. B. S. (2007). O café conilon em sistemas agroflorestais. In R. G. Ferrão, A. F. A. Fonseca, S. M. Bragança, M. A. G. Ferrão, \& L. H. DeMuner (Eds.), Café Conilon (pp. 375-389). Vitória, Brazil: Incaper.

Dardengo, M. C. J. D., De Sousa, E. F., Dos Reis, E. F., \& Gravina, G. De A. (2013). Crescimento e qualidade de mudas de café conilon produzidas em diferentes recipientes e níveis de sombreamento. Coffee Science, $8(4), 500-509$.

Engel, V. L. (1989). Influência do sombreamento sobre o crescimento de mudas de essências nativas, concentração de clorofila nas folhas e aspectos de anatomia (Master of Science Thesis, Escola Superior de Agricultura Luiz de Queiroz, Piracicaba, Brazil).

Estivariz-Coca, J. J. (1997). Efecto de sombra sobre la floración y producción de café (Coffea arabica var. Caturra), después de una poda completa en Turrialba, Costa Rica (p. 65, Master of Science Thesis, Centro Agronómico Tropical de Investigación y Enseñanza, Turrialba, Costa Rica).

Fahl, J. I., Carelli, M. L. C., Vega, J., \& Magalhães, A. C. (1994). Nitrogen and irradiance levels affecting net photosynthesis and growth of young coffee plants (Coffea arabica L.). Journal of Horticultural Science, 69(1), 161-169. https://doi.org/10.1080/14620316.1994.11515262

Fernandes, D. R. (1986). Manejo do Cafezal. In A. B. Rena (Ed.), Cultura do Cafeeiro (pp. 275-301). Piracicaba, Brazil: Associação Brasileira para a Pesquisa de Potassa e do Fosfato.

Frasina, V. A., Escobedo, J. F., \& Gomes, E. N. (2003). Estimativa da radiação fotossinteticamente ativa (PAR) em estufa de polietileno. Proceedings of the $3^{\text {rd }}$ Encontro de Energia no Meio Rural, 2000, Campinas, SP, Brazil.

Gerdemann, J. W., \& Nicolson, T. H. (1963). Spores of mycorrhizal Endogone species extracted from soil by wet sieving and decanting. Transactions of the British Mycological Society, 46(2), 235-244. https://doi.org/ 10.1016/S0007-1536(63)80079-0 
Givnish, T. J. (1988). Adaptation to sun and shade: A whole-plant perspective. Functional Plant Biology, 15(2), 63-92. https://doi.org/10.1071/PP9880063

Gomes, I. A. C., Castro, E. M. DE, Soares, A. M., Alves, J. D., Alvarenga, M. I. N., Alves, E., \& Fries, D. D. (2008). Alterações morfofisiológicas em folhas de Coffea arabica L. cv. "Oeiras" sob influência do sombreamento por Acacia mangium Willd. Ciência Rural, 38(1), 109-115. https://doi.org/10.1590/S010384782008000100018

IBGE. (2017) Relatório de estação geodésica. Retrieved from http://www.bdg.ibge.gov.br/bdg/pdf/relatorio. aspL1 $=93313$

ICO. (2018). About coffee. Retrieved from http://www.ico.org/pt/botanical_p.asp

Johansen, D. A. (1940). Plant microtechnique. New York, USA: McGraw-Hill Book Comp. Inc.

Kumar, D., \& Tieszeb, L. L. (1980). Photosynthesis in Coffea arabica. I. Effects of light and temperature. Experimental Agriculture, 16(1), 13-19. https://doi.org/10.1017/S0014479700010656

Lambers, H., Chapim, F. S., \& Pons, T. L. (1998). Plant physiological ecology. New York, USA: Springer. https://doi.org/10.1007/978-1-4757-2855-2

Lemos, C., \& Matsumoto, S. (2007). Avaliação do desenvolvimento vegetativo em cafeeiros sombreado e a pleno sol. Revista Brasileira de Agroecologia, 2(2), 1062-1065.

Lopes, E. S., Oliveira, E., Neptune, A. M.L., \& Moraes, F. R. P. (1983). Efeito da inoculação do cafeeiro com diferentes espécies de fungos micorrízicos vesicular-arbusculares. Revista Brasileira de Ciência do Solo, $7(2), 137-141$.

Matiello, J. B. (1995). Sistemas de Produção na Cafeicultura Moderna, Tecnologias de plantio adensado, renque mecanizado, arborização e recuperação de cafezais. Rio de Janeiro, Brazil: MM Produções Gráficas.

Moens, P. (1968). Investigaciones morfológicas, ecológicas y fisiológicas sobre cafetos. Turrialba, 18(3), 209-233.

Morais, H., Marur, C. J., Caramori, P. H., De Arruda Ribeiro, A. M., \& Gomes, J. C. (2003). Características fisiológicas e de crescimento de cafeeiro sombreado com guandu e cultivado a pleno sol. Pesquisa Agropecuaria Brasileira, 38(10), 1131-1137. https://doi.org/10.1590/S0100-204X2003001000001

Moraes Neto, S. P., Goncalves, J. L. De M., Takaki, M., \& Cenci, S. (2000). Crescimento de mudas de algumas espécies arbóreas que ocorrem na Mata Atlântica, em função do nível de luminosidade. Revista Árvore, 24(1), 35-45.

Moreira, F. M. S., Huising, E. J., \& Bignell, D. E. (2010). Manual de biologia dos solos-Amostragem e caracterização da biodiversidade. Lavras, Brazil: Editora UFLA.

Niinemets, U., Kull, O., \& Tenhunen, J. D. (1998). An analysis of light effects on foliar morphology, physiology, and light interception in temperate deciduous woody species of contrasting shade tolerance. Tree Physiology, 18(10), 681-696. https://doi.org/10.1093/treephys/18.10.681

O’Brien, T. P., Feder, N., \& Mccully, M. E. (1964). Polychromatic staining of plant cell walls by toluidine blue O. Protoplasma, 59(2), 368-373. https://doi.org/10.1007/BF01248568

Oguchi, R., Hikosaka, K., \& Hirose, T. (2005). Leaf anatomy as a constraint for photosynthetic acclimation: Differential responses in leaf anatomy to increasing growth irradiance among three deciduous trees. Plant, Cell and Environment, 28(7), 916-927. https://doi.org/10.1111/j.1365-3040.2005.01344.x

Paiva, L. C., Guimarães, R. J., \& Souza, C. S. (2001). Aspectos fisiologicos de mudas de cafeeiro (Coffea arabica L.) formadas a pleno sol. Simpósio de pesquisa dos cafés do Brasil. Vitória, Brazil: Embrapa Café.

Pandey, S., \& Kushwaha, R. (2005). Leaf anatomy and photosynthetic acclimation in Valeriana jatamansi L. grown under high and low irradiance. Photosynthetica, 43(1), 85-90. https://doi.org/10.1007/s11099005-5090-8

Pereira, E. B., Martins, F. R., Abreu, S. L. de, \& Rüther, R. (2017). Atlas Brasileiro da Energia Solar, 31. https://doi.org/978-85-17-00030-0

Phillips, J. M., \& Hayman, D. S. (1970). Improved procedures for cleaning roots and staining parasitic and vesicular-arbuscular mycorrhizal fungi for rapid assessment of infection. Transactions of the British Mycological Society, 55(1), 158-161. https://doi.org/10.1016/S0007-1536(70)80110-3 
Rena, A. B., \& Maestri, M. (1986). Fisiologia do cafeeiro. In A. B. Rena, E. Malavolta, M. Rocha, \& T. Yamada (Eds.), Cultura do cafeeiro: Fatores que afetam a produtividade. Piracicaba, Brazil: Associação Brasileira para Pesquisa da Potassa e do Fosfato.

Ricci, M. S. F., Cocheto Junior, D. G. C., \& Almeida, F. F. D. (2013). Microweather conditions, phenology and external morphology of coffee trees in shaded and full sun systems. Coffee Science, 8(3), 379-388.

Ross, J. P., \& Daniels, B. A. (1982). Hyperparasitism of endomycorrhizal fungi. In N. C. Schenck (Ed.), Methods and Principles of Mycorrhizal Research (pp. 55-58). St. Paul, USA: The American Phytophatological Society Press.

Siqueira, J. O., \& Colllozi-Filho, A. (1986). Micorrizas vesículo-arbusculares em mudas de cafeeiro. II. Efeito do fósforo no estabelecimento e funcionamento da simbiose. Revista Brasileira de Ciência do Solo, 10(3), 207-211.

Siqueira, J. O., Saggin-Junior, O. J., Flores-Aylas, W. W., \& Guimarães, P. T. G. (1998). Arbuscular mycorrhizal inoculation and superphosphate application influence plant development and yield of coffee in Brazil. Mycorrhiza, 7(6), 293-300. https://doi.org/10.1007/s005720050195

Stein, L. N. (2017). Coffee Certifications as Potential Pathways to Women's Empowerment in Costa Rica (Master of Science Thesis, University of Montana, Montana, USA).

Voltan, R. B. Q., Fahl, J. I., \& Carelli, M. L. C. (1992). Variação na anatomia foliar de cafeeiros submetidos a diferentes intensidades luminosas. Revista Brasileira de Fisiologia Vegetal, 4(2), 99-105.

\section{Copyrights}

Copyright for this article is retained by the author(s), with first publication rights granted to the journal.

This is an open-access article distributed under the terms and conditions of the Creative Commons Attribution license (http://creativecommons.org/licenses/by/4.0/). 